\title{
A STUDY OF CARDIOPULMONARY ALTERATIONS IN PATIENTS WITH SICKLE CELL DISEASE AND ITS VARIANTS ${ }^{1}$
}

\author{
By BRIAN J. SPROULE, E. RICHARD HALDEN, AND WILLIAM F. MILLER \\ (From the Cardiopulmonary Laboratory, Department of Internal Medicine, University of Texas
} Southwestern Medical School, and Parkland Memorial Hospital, Dallas, Texas)

(Submitted for publication September 3, 1957; accepted November 21, 1957)

It has recently become apparent that a high proportion of individuals who possess $\mathrm{S}$ type hemoglobin exhibit significant desaturation of the arterial blood. In 1942 Klinefelter (1) found arterial oxygen saturations of 89 and 91 per cent in two patients, and in 1943 Reinhard, Moore, Dubach, and Wade (2) found values ranging from 74.2 to 90.8 per cent saturation in one patient with sickle cell disease. Leight, Snider, Clifford, and Hellems (3) studied 13 patients with sickle cell disease in 1954, 10 of whom had arterial $\mathrm{O}_{2}$ desaturation. Within the past year reports from this laboratory $(4,5)$ and from Jensen, Rucknagel, and Taylor (6) indicate that desaturation of arterial blood exists in most people who possess $\mathrm{S}$ type hemoglobin. The exact mechanism responsible for this phenomenon has not been elucidated.

The various possibilities may be distinguished with fair accuracy by determining alveolar and arterial oxygen tensions and calculating A-a oxygen tension gradients at three levels of oxygenation. If desaturation is due to hypoventilation, no appreciable gradient exists at any level of oxygenation and $\mathrm{CO}_{2}$ retention is usually evident. Any increase in A-a gradient must, therefore, be due to some other mechanism. Lilienthal, Riley, Proemmel, and Franke (7) suggested that one might distinguish between a diffusion defect and veno-arterial admixture by measurement of the effective alveolar-arterial gradient at two levels of oxygenation, one of which produces significant desaturation of arterial blood. Low levels of inspired $\mathrm{O}_{2}$ (12 to 14 per cent) exaggerate the effects of impaired diffusion and minimize the effects of veno-arterial admixture. Veno-arterial admixture, thus delineated, may be either through actual anatomical communications, or the result of reduction in the ventilation-perfusion ratios.

\footnotetext{
1 This work is part of a project being supported by a grant from the United States Public Health Service (H-2113).
}

If due to uneven ventilation, the gradient is eliminated by administration of 100 per cent oxygen since, during pure oxygen breathing, even minimally ventilated alveoli eventually attain an oxygen tension approaching atmospheric pressure. Therefore, as shown by Berggren (8), the A-a gradient measured during the inspiration of pure oxygen may be taken as a measure of shunting of blood from the venous to the arterial side of the circulation.

In the following studies, these concepts were utilized in an effort to clarify the mechanism whereby desaturation occurs in individuals with sickle cell anemia and its variants. In addition, observations were made on the hemodynamic alterations accompanying cardiomegaly in these states and on the relationship of intravascular oxygen tension and degree of sickling to the sickle cell crisis.

\section{MATERIAL AND METHODS}

Alveolar-arterial oxygen gradients were measured during the inspiration of low oxygen, room air, and 100 per cent oxygen on 21 subjects possessing $S$ type hemoglobin, 4 of whom had hemoglobin electrophoretic patterns characterized as SA (sickle cell trait), 4 as SC (sickle cell hemoglobin C disease), and 13 as SS (sickle cell disease). The 0.5 second timed expiratory capacities and vital capacities were measured on all subjects using a Gaensler-Collins vitalometer. Cardiac catheterization was done in 10 members of the group. Quantitation of the in vivo sickling phenomenon on both the arterial and venous sides of the circulation, along with measurement of serum hemoglobin levels, was also undertaken.

All measurements were made in the supine position. No premedication was routinely given although the 10 patients who underwent cardiac catheterization received procaine amide hydrochloride (Pronesty1®), $250 \mathrm{mg}$., and penicillin, 600,000 units, on the morning of the studies.

Arterial blood collections were made from an indwelling Cournand needle inserted into the brachial artery; venous blood samples were obtained from peripheral veins in both arms. Gas mixtures were breathed through a Rudolph two-way breathing valve with Bennett-seal mouthpiece, and expired air was collected in a Douglas 
bag. Arterial blood was analyzed for $\mathrm{CO}_{2}$ and $\mathrm{O}_{2}$ content, $\mathrm{pH}, \mathrm{O}_{2}$ tension $\left(\mathrm{pO}_{2}\right)$, per cent sickling, and quantity of serum hemoglobin. Venous blood was analyzed for $\mathrm{pO}_{2}$ or $\mathrm{O}_{2}$ content, or both, per cent sickling, and serum hemoglobin. Venous $\mathrm{pH}$ was determined in the blood samples analyzed for $\mathrm{O}_{2}$ content, and $\mathrm{O}_{2}$ tensions were calculated using these values, and the $\mathrm{O}_{2}$ dissociation curves of Dill (9) in those patients from whom directly measured venous $\mathrm{O}_{2}$ tensions were not obtained. Carbon dioxide and $\mathrm{O}_{2}$ contents were determined by the method of Van Slyke and Neill, duplicate determinations being required to check within 0.1 volumes per cent. Hydrogen ion concentration was measured at $37.5^{\circ} \mathrm{C}$. on a Cambridge research model $\mathrm{pH}$ meter. On the first few patients $\mathrm{pO}_{2}$ values were determined using a polarograph with a dropping mercury electrode for high $\mathrm{O}_{2}$ tension $(>100 \mathrm{~mm} . \mathrm{Hg}$ ) and the microbubble equilibration of Riley, Proemmel, and Franke (10) for physiologic $\mathrm{O}_{2}$ tensions. Later, a new polarographic technique employing the Clark electrode was utilized to measure $\mathrm{O}_{2}$ tensions at all levels. The accuracy and reliability of the method at all levels of $\mathrm{O}_{2}$ tension have been established by a comparison between directly measured $\mathrm{O}_{2}$ tensions and those calculated from simultaneously drawn samples of blood analyzed on the Van Slyke manometric apparatus (11). It was found that, over a $\mathrm{pO}_{2}$ range of 23 to $97 \mathrm{~mm}$. $\mathrm{Hg}$, the relation between calculated and polarographically determined values was very nearly linear, the correlation coefficient being $+0.98 \quad(n=57)$. Comparison over the same range of $\mathrm{pO}_{2}$ between the microbubble technique of Riley and the polarographic method yields similar results. At higher levels of $\mathrm{pO}_{2}$, blood was equilibrated with tank mixtures, the $\mathrm{pO}_{2}$ of which varied from 133 to $710 \mathrm{~mm}$. $\mathrm{Hg}$ as determined from Scholander analyses (12). Again, the relationship between the known $\mathrm{pO}_{2}$ and that determined polarographically was linear, variations between individual pairs being negligible.

Blood for analysis of per cent sickling was withdrawn anaerobically into Zenker's solution and stained with safranin, utilizing a technique described elsewhere (13). Counts were done on 1,000 to 1,500 cells. Serum hemoglobin was determined using Crosby's modification of the benzidine method (14).

Expired air was analyzed for $\mathrm{O}_{2}$ content on a Beckman E-2 magnetic $\mathrm{O}_{2}$ analyzer and for $\mathrm{CO}_{2}$ content on a Liston-Becker infrared $\mathrm{CO}_{2}$ analyzer. These instruments were standardized daily with known gas mixtures and were checked periodically with a Scholander microanalyzer. Gas volumes were measured with a Tissot spirometer and were corrected either to BTPS or to STPD. Physiological dead space was calculated on all patients using a conventional equation (15).

As soon as the subject appeared to have attained a steady state, a gas collection was made, blood samples being withdrawn midway during the collection. The per cent of oxygen in inspired air was checked on the inspiratory side of the breathing valve with the Beckman $\mathrm{O}_{2}$ analyzer during the collection of expired gas.

On completion of the ambient air measurements, a low oxygen mixture was administered for 30 minutes; all measurements were then repeated. Since we were critically concerned with the effects of low $\mathrm{pO}_{2}$ on the in vivo sickling phenomenon, the levels of $\mathrm{O}_{2}$ used ( 9 to 15 per cent) were occasionally lower than those recommended by Riley and Cournand (16).

One hundred per cent $\mathrm{O}_{2}$ was then administered for the same length of time, at the end of which the blood and gas collections were once again repeated. Adequate washout of $\mathrm{N}_{2}$ by the 100 per cent $\mathrm{O}_{2}$ was periodically checked by monitoring expired air on a nitrogen meter.

The alveolar-arterial gradients for $\mathrm{O}_{2}$ were determined using the alveolar air equation to calculate the alveolar $\mathrm{pO}_{2}$. Carbon dioxide tension for use in this equation was derived from the measured arterial $\mathrm{CO}_{2}$ content (Van Slyke), and $\mathrm{pH}$ by use of the Singer-Hastings nomogram (17). The directly measured (polarographic) value for arterial $\mathrm{pO}_{2}$ was then subtracted from the calculated alveolar $\mathrm{pO}_{2}$. To use the A-a gradient obtained in this way for calculation of the approximate magnitude of veno-arterial admixture, it is necessary to perform the determinations while 100 per cent $\mathrm{O}_{2}$ is being breathed and also to know the $\mathrm{AV} \mathrm{O}_{2}$ difference (18). In the 10 catheterized patients, this was measured directly. In eight additional patients, cardiac outputs were estimated at all levels of oxygenation by a modification of a $\mathrm{CO}_{2}$ method described by Forssander (19). Comparisons between cardiac outputs determined in this way with those determined simultaneously by the conventional Fick method showed a systematic discrepancy for which a correction factor was worked out. The corrected cardiac output could then be used along with the $\mathrm{O}_{2}$ consumption to calculate $\mathrm{AV} \mathrm{O}_{2}$ difference. In the 10 remaining determinations an $\mathrm{AV} \mathrm{O}_{2}$ difference of 3.75 volumes per cent (which was the average of the foregoing) was assumed. The magnitude of right-to-left shunts may be estimated as follows (18):

$$
\text { Per cent shunt }=100-(\mathrm{Y} / \mathrm{Y} \& \mathrm{G}) \times 100 \text {, }
$$

where $\mathrm{Y}=\mathrm{AV} \mathrm{O}_{2}$ difference, $\mathrm{G}=\mathrm{Gradient}$ in $\mathrm{mm}$. $\mathrm{Hg}$ times 0.003 (Sendroy factor to convert dissolved $\mathrm{O}_{2}$ at $37.5^{\circ} \mathrm{C}$. to volumes per cent).

Right heart catheterization, when done, was performed in the conventional manner. A wedge pressure was recorded and the catheter was then withdrawn and left in the pulmonary artery during gas exchange studies. Pressures were recorded by means of a pressure transducer and a multichannel recorder. Dye curves were obtained using an ear oximeter, following the injection of $\mathrm{T}-1824$ dye into the right atrium.

Radioactive chromium blood volumes were done on seven of the catheterized patients.

\section{RESULTS}

\section{A. Room air breathing}

Arterial $\mathrm{O}_{2}$ desaturation was present in 16 of the 21 patients (Table $\mathrm{I}$ ), the mean arterial $\mathrm{O}_{2}$ saturation being 89.1 per cent, the mean arterial 





oxygen tension $63.2 \mathrm{~mm} . \mathrm{Hg}$, and the average A-a gradient $36.0 \mathrm{~mm}$. Hg. Arterial saturation was normal in six patients (Table II) who had a mean arterial saturation of 96.6 per cent, mean oxygen tension of $90.7 \mathrm{~mm}$. $\mathrm{Hg}$, and an average A-a gradient of $9.6 \mathrm{~mm}$. $\mathrm{Hg}$. It might be noted that Patient No. 21, J. M., moved from the desaturated to the saturated group when repeat studies were performed after an interval of two months. The total of desaturated plus saturated subjects therefore sums to 22 rather than 21 since Patient J. M. is counted twice by this method. All three types of hemoglobin electrophoretic patterns were found in both the desaturated (11 SS, $3 \mathrm{SA}$, and $2 \mathrm{SC}$ ) and the normally saturated (2 SS, $2 \mathrm{SC}$, and 1 $\mathrm{SA})$ groups. The mean hemoglobin of the normally saturated subjects was $10.18 \mathrm{Gm}$. The per cent of sickling in venous and arterial blood was directly related to the $\mathrm{pO}_{2}$; the levels of $\mathrm{pO}_{2}$ required to produce sickling, however, differed according to the hemoglobin variant (SA, SC, or SS) (4). The venous oxygen tensions varied greatly; abnormally high readings, closely approximating simultaneously drawn arterial oxygen tensions, appeared in numerous instances. Values for oxygen tension in determinations Nos. 6, 7, $9,11,15,17,21$, and 25 were derived from $\mathrm{O}_{2}$ content (Van Slyke) and $\mathrm{pH}$. Of these, determinations Nos. 9 and 17 demonstrated directly the abnormally high $\mathrm{O}_{2}$ content suggested by polarographic measurement of $\mathrm{O}_{2}$ tension in a number of other patients (Nos. 1, 2, 4, and 12). Simultaneously drawn pulmonary artery blood was significantly lower in oxygen tension than the arterialized peripheral venous blood.

\section{B. Low oxygen breathing}

In Table III are listed the results obtained when the same patients were evaluated after breathing a low concentration of oxygen for 30 minutes. This phase of the complete study was usually omitted on repeat determinations, but in order to facilitate comparisons, numbers corresponding to Tables I and II have been retained. The average gradient in the desaturated subjects (determinations Nos. 1 to 21) was $14.0 \mathrm{~mm}$. $\mathrm{Hg}$ as compared to a gradient of $9.4 \mathrm{~mm}$. Hg in the completely saturated individuals. Without exception, the A-a gradient was less than the room air values when

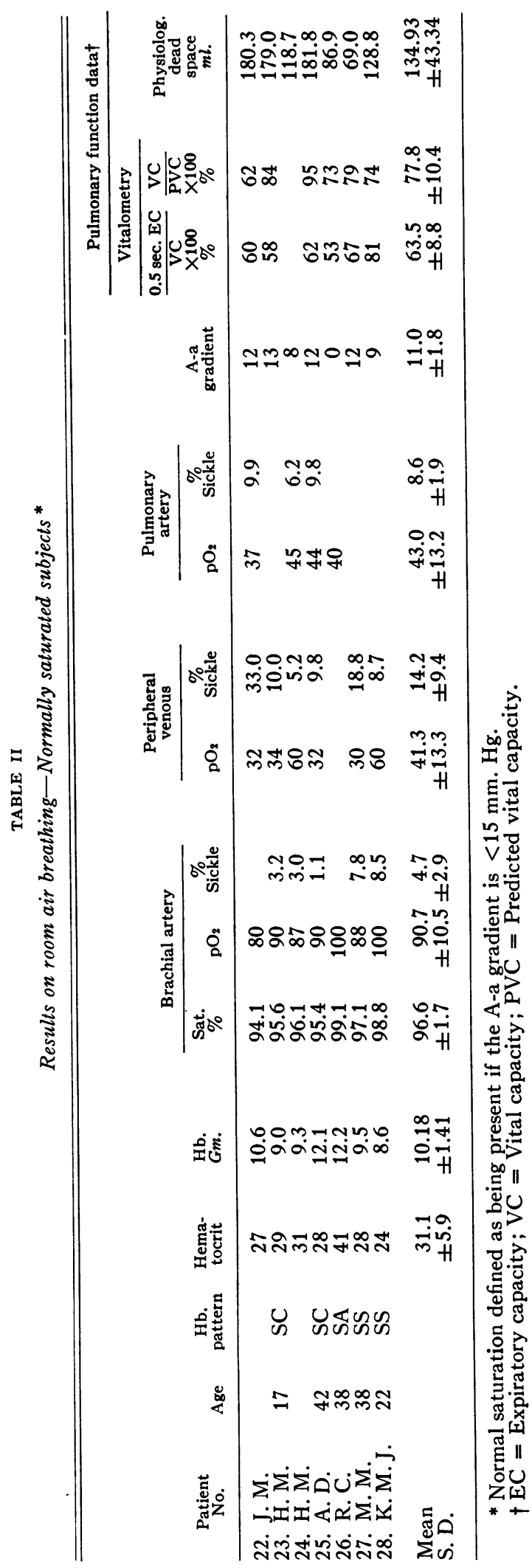


TABLE III

Results on low $\mathrm{O}_{2}$ breathing

\begin{tabular}{|c|c|c|c|c|c|c|c|c|}
\hline \multirow[b]{2}{*}{$\begin{array}{l}\text { Patient } \\
\text { No. }\end{array}$} & \multirow{2}{*}{$\begin{array}{c}\text { Hb. } \\
\text { electro- } \\
\text { phoretic } \\
\text { pattern }\end{array}$} & \multirow[b]{2}{*}{$\begin{array}{c}\mathrm{O}_{2} \text { in } \\
\text { inspired } \\
\text { gas (\%) }\end{array}$} & \multicolumn{3}{|c|}{ Arterial } & \multicolumn{2}{|c|}{ Venous } & \multirow[b]{2}{*}{ 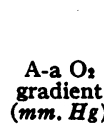 } \\
\hline & & & $\begin{array}{l}\text { Sat. } \\
(\%)\end{array}$ & $\underset{\left(m m . H_{g}\right)}{\stackrel{\mathrm{pO}_{2}}{(m)}}$ & $\begin{array}{c}\% \\
\text { Sickle }\end{array}$ & $\underset{(m m . H g)^{*}}{\mathrm{pO}_{2}}$ & $\begin{array}{c}\% \\
\text { Sickle }\end{array}$ & \\
\hline $\begin{array}{l}\text { 1. J. A. } \\
\text { 3. E. R. } \\
\text { 5. W.Y. } \\
\text { 7. R. C. R. } \\
\text { 9. K. G. } \\
\text { 11. R.T. } \\
\text { 12. E. D. } \\
\text { 13. T. P. } \\
\text { 14. R. W. } \\
\text { 15. C. J. } \\
\text { 16. C. P. } \\
\text { 17. W.S. } \\
\text { 18. S. A. } \\
\text { 19. E. M. } \\
\text { 20. B. T. } \\
\text { 21. J. M. }\end{array}$ & $\begin{array}{l}\text { SS } \\
\text { SS } \\
\text { SS } \\
\text { SS } \\
\text { SS } \\
\text { SS } \\
\text { SS } \\
\text { SS } \\
\text { SS } \\
\text { SS } \\
\text { SS } \\
\text { SA } \\
\text { SA } \\
\text { SA } \\
\text { SC } \\
\text { SC }\end{array}$ & $\begin{array}{r}15.9 \\
11.7 \\
11.6 \\
9.2 \\
11.1 \\
14.1 \\
16.0 \\
8.9 \\
10.5 \\
11.1 \\
10.4 \\
11.1 \\
9.5 \\
10.9 \\
10.2 \\
11.5\end{array}$ & $\begin{array}{l}78.0 \\
47.0 \\
68.0 \\
50.8 \\
54.4 \\
73.0 \\
82.0 \\
54.9 \\
51.0 \\
80.0 \\
51.8 \\
66.4 \\
60.0 \\
60.0 \\
69.7 \\
54.4\end{array}$ & $\begin{array}{l}43 \\
29 \\
40 \\
30 \\
31 \\
34 \\
46 \\
28 \\
28 \\
46 \\
28 \\
29 \\
30 \\
29 \\
31 \\
28\end{array}$ & $\begin{array}{r}7.0 \\
56.0 \\
44.5 \\
37.0 \\
45.7 \\
29.2 \\
15.4 \\
41.0 \\
40.1 \\
11.6 \\
40.6 \\
16.3 \\
3.1 \\
3.0 \\
12.1 \\
27.0\end{array}$ & $\begin{array}{l}36 \\
14 \\
13 \\
37 \\
49 \\
12 \\
19 \\
20 \\
10 \\
37 \\
13 \\
18 \\
22 \\
18\end{array}$ & $\begin{array}{r}7.0 \\
69.2 \\
19.0 \\
75.6 \\
63.0 \\
33.8 \\
20.0 \\
70.6 \\
57.9 \\
40.8 \\
62.3 \\
6.5 \\
25.0 \\
3.0 \\
15.0 \\
50.0\end{array}$ & $\begin{array}{r}30.0 \\
29.0 \\
8.4 \\
5.0 \\
13.6 \\
25.0 \\
28.0 \\
4.0 \\
11.0 \\
0.0 \\
12.0 \\
10.0 \\
12.0 \\
13.0 \\
11.5 \\
11.4\end{array}$ \\
\hline $\begin{array}{l}\text { Mean } \\
\text { S. D. }\end{array}$ & & & $\begin{array}{r}62.4 \\
\pm 3.5\end{array}$ & $\begin{array}{r}33.1 \\
\pm 6.9\end{array}$ & & & & $\begin{array}{r}14.0 \\
\pm 8.8\end{array}$ \\
\hline $\begin{array}{l}\text { 23. H. M. } \\
\text { 25. A. D. } \\
\text { 26. R. C. } \\
\text { 27. M. M. } \\
\text { 28. K. M. J. }\end{array}$ & $\begin{array}{l}\text { SC } \\
\text { SA } \\
\text { SA } \\
\text { SS } \\
\text { SS }\end{array}$ & $\begin{array}{r}11.4 \\
14.5 \\
17.6 \\
12.9 \\
9.6\end{array}$ & $\begin{array}{l}68.0 \\
87.0 \\
94.8 \\
68.0 \\
50.1\end{array}$ & $\begin{array}{l}34 \\
55 \\
82 \\
34 \\
40\end{array}$ & $\begin{array}{r}16.0 \\
2.4 \\
18.1 \\
55.8\end{array}$ & $\begin{array}{l}25 \\
35 \\
\\
24 \\
42\end{array}$ & $\begin{array}{r}21.0 \\
4.6 \\
32.3 \\
38.3\end{array}$ & $\begin{array}{r}13.0 \\
11.0 \\
8.0 \\
12.0 \\
3.0\end{array}$ \\
\hline $\begin{array}{l}\text { Mean } \\
\text { S. D. }\end{array}$ & & & 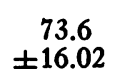 & $\begin{array}{r}49 \\
\pm 18\end{array}$ & & & & $\begin{array}{r}9.4 \\
\pm 3.6\end{array}$ \\
\hline
\end{tabular}

* Abnormally high venous $\mathrm{pO}_{2}$ 's-Nos. $3,11,12,17,28$.

low oxygen was breathed. Peculiar variations in the venous $\mathrm{pO}_{2}$ were again seen. On five occasions, the venous $\mathrm{pO}_{2}$ was higher than simultaneously determined arterial $\mathrm{pO}_{2}$. In determination No. 17 this abnormality was demonstrated by simultaneous measurement of arterial and venous $\mathrm{O}_{2}$ content, which has, in Table III, been converted to venous $\mathrm{O}_{2}$ tension by use of $\mathrm{pH}$ and the $\mathrm{O}_{2}$ dissociation relationship. Venous blood was found to contain fewer sickled cells than arterial blood (inferentially suggesting a higher $\mathrm{pO}_{2}$ in venous than in arterial blood) on three occasions.

\section{One hundred per cent oxygen breathing}

The values obtained when the patients breathed 100 per cent $\mathrm{O}_{2}$ (Table IV) indicate that a significant degree of right-to-left shunting existed in most of these subjects. The individuals who exhibited arterial $\mathrm{O}_{2}$ desaturation while breathing room air had, while breathing pure oxygen, an average A-a gradient of $165.4 \mathrm{~mm}$. $\mathrm{Hg}$ with a calculated shunt of 11.96 per cent. That desatura- tion is related to shunting is suggested by the fact that the six normally saturated individuals, when studied with pure oxygen, showed an average A-a gradient of only $28.3 \mathrm{~mm}$. $\mathrm{Hg}$ with a calculated shunt of 1.93 per cent. One patient (J. A., Nos. 1 and 2) showed a gross increase in the degree of shunting when her hemoglobin was increased from 5.0 to $11.0 \mathrm{Gm}$. by transfusion. Measurement of venous $\mathrm{pO}_{2}$ in a number of cases showed evidence of marked arterialization, which became more obvious during 100 per cent oxygen breathing than at lower levels.

\section{Cardiac catheterization data}

Hemodynamic data on 10 patients are set out in Table V. (The numbers identify the patients as listed in previous tables.) With the exception of Subject No. 26, all had radiologic evidence of cardiomegaly. In all subjects the pulmonary vascular resistance was within normal limits. The average cardiac indexes were appreciably elevated and the total blood volumes, done by the radio- 
active chromium method, were increased in all desaturated subjects. The appearance time of all $\mathrm{T}-1824$ dye curves was normal.

\section{E. Additional data}

The results of analysis of blood samples obtained simultaneously from two peripheral veins, the brachial artery and, in two instances, from the pulmonary artery, are presented in Table VI. These data offer further evidence of abnormally high oxygen contents in certain peripheral veins.

The ratio $(0.5 \mathrm{sec}$. $\mathrm{EC} / \mathrm{VC}) \times 100$ is indicative of a significant obstructive ventilatory defect if less than 60 per cent; vital capacity is indicative of a significant restrictive ventilatory defect if it is less than 85 per cent of the predicted normal (20). The desaturated subjects were found to have an average ( 0.5 second $\mathrm{EC} / \mathrm{VC}$ ) ratio of $67.8 \pm 5.8$ per cent, with an average vital capacity of $64.6 \pm$ 12.2 per cent of predicted normal. These values are suggestive of a pure restrictive ventilatory defect. Timed vitalometry on the normally saturated individuals showed virtually normal values.

The average physiological dead space was within normal limits in both the desaturated (129.15 \pm $40.21 \mathrm{ml}$.) and the normally saturated (134.93 \pm $43.34 \mathrm{ml}$.) subjects.

Serum hemoglobins were unaltered by the inhalation of various oxygen mixtures and were also unchanged when measured on 10 of these patients during periods of clinical "crises."

\section{DISCUSSION}

\section{Arterial oxygen desaturation}

These results confirm the existence of desaturation of the arterial blood in a majority of subjects possessing the abnormal $\mathrm{S}$ type of hemoglobin. The phenomenon is not clearly related either to the specific hemoglobin electrophoretic pattern or to the degree of associated anemia.

TABLE IV

Results on 100 per cent $\mathrm{O}_{2}$ breathing

\begin{tabular}{|c|c|c|c|c|c|c|c|}
\hline \multirow[b]{2}{*}{$\begin{array}{l}\text { Patient } \\
\text { No. }\end{array}$} & \multirow{2}{*}{$\begin{array}{l}\text { Hb. } \\
\text { electro- } \\
\text { phoretic } \\
\text { pattern }\end{array}$} & \multicolumn{2}{|c|}{ Arterial* } & \multicolumn{2}{|c|}{ Venous } & \multirow[b]{2}{*}{$\underset{\substack{\text { A-a } \\
\text { gradient } \\
(m \boldsymbol{m} . \mathrm{Hg})}}{ }$} & \multirow[b]{2}{*}{$\begin{array}{l}\text { Calc. \% } \\
\text { shunt }\end{array}$} \\
\hline & & $\begin{array}{c}\mathrm{pO}_{2} \\
(m m . H g)\end{array}$ & $\begin{array}{c}\% \\
\text { Sickle }\end{array}$ & $\begin{array}{c}\mathrm{pO}_{2} \\
(m m . H g\end{array}$ & $\begin{array}{c}\% \\
\text { Sickle }\end{array}$ & & \\
\hline $\begin{array}{l}\text { 1. J. A. } \\
\text { 2. J.A. } \\
\text { 4. E. R. } \\
\text { 5. W. Y. } \\
\text { 7. R. C. R. } \\
\text { 8. R. C. R. } \\
\text { 9. K. G. } \\
\text { 11. R. T. } \\
\text { 12. E. D. } \\
\text { 13. T. P. } \\
\text { 14. R. W. } \\
\text { 15. C. J. } \\
\text { 16. C. P. } \\
\text { 17. W.S. } \\
\text { 18. S. A. } \\
\text { 19. E. M. } \\
\text { 20. B.T. } \\
\text { 21. J. M. }\end{array}$ & $\begin{array}{l}\text { SS } \\
\text { SS } \\
\text { SS } \\
\text { SS } \\
\text { SS } \\
\text { SS } \\
\text { SS } \\
\text { SS } \\
\text { SS } \\
\text { SS } \\
\text { SS } \\
\text { SA } \\
\text { SA } \\
\text { SA } \\
\text { SC } \\
\text { SC }\end{array}$ & $\begin{array}{l}542 \\
191 \\
374 \\
411 \\
367 \\
470 \\
528 \\
596 \\
482 \\
550 \\
519 \\
400 \\
516 \\
504 \\
584 \\
538 \\
501 \\
344\end{array}$ & $\begin{array}{r}1.6 \\
10.5 \\
3.2 \\
7.1 \\
6.2 \\
1.6 \\
2.3 \\
1.2 \\
5.4 \\
1.8 \\
0.4 \\
2.3 \\
2.2 \\
2.4 \\
3.0 \\
0.4 \\
0.2\end{array}$ & $\begin{array}{c}48 \\
83 \\
300 \\
300+ \\
60 \\
88 \\
339 \\
256 \\
308 \\
319 \\
50 \\
120 \\
53 \\
30 \\
71 \\
41 \\
36 \\
57\end{array}$ & $\begin{array}{r}3.1 \\
10.5 \\
45.0 \\
24.0 \\
3.7 \\
2.2 \\
2.5 \\
1.3 \\
0.9 \\
8.7 \\
2.2 \\
4.4 \\
11.9 \\
3.2 \\
3.0 \\
10.0\end{array}$ & $\begin{array}{r}108 \\
457 \\
290 \\
257 \\
239 \\
208 \\
145 \\
79 \\
194 \\
112 \\
145 \\
264 \\
152 \\
155 \\
89 \\
129 \\
162 \\
290\end{array}$ & $\begin{array}{r}8.3 \\
27.4 \\
27.0 \\
17.6 \\
14.2 \\
17.4 \\
8.8 \\
6.8 \\
16.0 \\
9.4 \\
9.4 \\
16.6 \\
11.0 \\
11.4 \\
6.9 \\
9.6 \\
11.9 \\
11.0\end{array}$ \\
\hline $\begin{array}{l}\text { Mean } \\
\text { S. D. }\end{array}$ & & $\begin{array}{r}400.8 \\
\pm 187.2\end{array}$ & & & & $\begin{array}{r}165.4 \\
\pm 108.0\end{array}$ & $\begin{array}{r}11.5 \\
\pm 7.2\end{array}$ \\
\hline $\begin{array}{l}\text { 22. J. M. } \\
\text { 24. H. M. } \\
\text { 25. A. D. } \\
\text { 26. R. C. } \\
\text { 27. M. M. } \\
\text { 28. K. M. J. }\end{array}$ & $\begin{array}{l}\text { SC } \\
\text { SA } \\
\text { SA } \\
\text { SS } \\
\text { SS }\end{array}$ & $\begin{array}{l}606 \\
674 \\
660 \\
671 \\
596 \\
687\end{array}$ & $\begin{array}{l}2.2 \\
1.8 \\
0.4 \\
2.8 \\
1.8\end{array}$ & $\begin{array}{r}50 \\
35 \\
27 \\
338 \\
58\end{array}$ & $\begin{array}{r}16.7 \\
11.2 \\
\\
4.6 \\
20.2\end{array}$ & $\begin{array}{r}66 \\
8 \\
19 \\
1 \\
57 \\
19\end{array}$ & $\begin{array}{l}4.4 \\
1.0 \\
1.8 \\
0.0 \\
4.4 \\
0.0\end{array}$ \\
\hline $\begin{array}{l}\text { Mean } \\
\text { S. D. }\end{array}$ & & $\begin{array}{r}649.0 \\
\pm 34.9\end{array}$ & & & & $\begin{array}{r}28.3 \\
\pm 24.4\end{array}$ & $\begin{array}{r}1.9 \\
\pm 1.9\end{array}$ \\
\hline
\end{tabular}

\footnotetext{
* The arterial $\mathrm{O}_{2}$ saturation was 100 per cent in all these determinations,
} 
TABLE V

Results of cardiac catheterization

\begin{tabular}{|c|c|c|c|c|c|c|c|c|c|c|c|}
\hline \multirow[b]{2}{*}{$\begin{array}{c}\text { Patient } \\
\text { No. }\end{array}$} & \multirow{2}{*}{$\begin{array}{l}\text { Hb. } \\
\text { electro- } \\
\text { phoretic } \\
\text { pattern }\end{array}$} & \multirow{2}{*}{$\begin{array}{c}\text { Wedge } \\
\text { press. } \\
m m . H g\end{array}$} & \multirow{2}{*}{$\underset{m m . H g}{\text { PA }}$} & \multirow{2}{*}{$\underset{\substack{\text { RV } \\
\text { press. } \\
m m . H g}}{.}$} & \multirow{2}{*}{$\underset{\text { press. }}{\mathrm{RA}}$} & \multirow{2}{*}{$\begin{array}{l}\text { Pulm. } \\
\text { vasc.; } \\
\text { res.* }\end{array}$} & \multirow{2}{*}{$\begin{array}{c}\text { Dye } \\
\text { curve } \\
\text { A.T.† }\end{array}$} & \multicolumn{2}{|c|}{ Cardiac index } & \multirow{2}{*}{$\begin{array}{c}\text { Total } \\
\text { blood vol. } \\
m l .\end{array}$} & \multirow{2}{*}{$\begin{array}{c}\text { Blood } \\
\text { volume } \\
m l . / K g .\end{array}$} \\
\hline & & & & & & & & $\underset{\text { air }}{\text { Room }}$ & $\begin{array}{c}100 \% \\
\mathrm{O}_{2}\end{array}$ & & \\
\hline 2. I. A. & SS & 8.0 & $20 / 8$ & $25 / 3$ & 4 & 1.63 & 8 & 5.3 & 4.9 & 5,360 & 126 \\
\hline 4. E. R. & SS & 15.0 & $43 / 12$ & $49 / 9$ & 8 & 2.04 & 9 & 5.4 & 4.3 & 6,503 & 121 \\
\hline 6. W. Y. & SS & 8.0 & $21 / 10$ & $19 / 3$ & 8 & 1.02 & 8 & 4.8 & 3.9 & 4,280 & 73 \\
\hline 8. R. C. R. & SS & 7.9 & $26 / 10$ & $30 / 6$ & 6 & 1.48 & 7 & 4.9 & 6.1 & 8,117 & 135 \\
\hline 10. K. G. & SS & & & & 6 & & 8 & 3.6 & 2.6 & 3,585 & 72 \\
\hline 12. E. D. & SS & 4.5 & $18 / 8$ & $17 / 0$ & 2 & 2.13 & 9 & 4.9 & 7.7 & & \\
\hline 22. J. M. & $\mathrm{SC}$ & 8.0 & $20 / 10$ & $23 / 6$ & 7 & 1.37 & 10 & 3.5 & 4.4 & 4,251 & 84 \\
\hline 24. H. M. & $\mathrm{SC}$ & 8.5 & $16 / 7$ & $20 / 6$ & 3 & 0.50 & 8 & 3.4 & 3.1 & 4,367 & 80 \\
\hline 25. A. D. & $\mathrm{SC}$ & 3.0 & $14 / 6$ & $17 / 0$ & 3 & 2.72 & 10 & 3.1 & 3.8 & & \\
\hline 26. R. C. & $\mathrm{SA}$ & 5.0 & $14 / 5$ & $15 / 3$ & 3 & 1.28 & 8 & 3.5 & 4.2 & & \\
\hline $\begin{array}{l}\text { Mean } \\
\text { S. D. }\end{array}$ & & & & & & $\begin{array}{r}1.53 \\
\pm 1.64\end{array}$ & $\begin{array}{r}8.5 \\
\pm 0.9\end{array}$ & $\begin{array}{r}4.24 \\
\pm 0.60\end{array}$ & $\begin{array}{r}4.5 \\
\pm 1.4\end{array}$ & $\begin{array}{r}5,209 \\
+1,478\end{array}$ & $\begin{array}{r}98.7 \\
\pm 23.4\end{array}$ \\
\hline
\end{tabular}

* Pressure drop (pulmonary artery mean pressure-wedge pressure) in $\mathrm{mm}$. of $\mathrm{Hg}$ per liters blood flow per minute per square meter.

$\dagger$ Appearance time (seconds) of T-1824 dye following injection into right atrium.

$\ddagger$ Blood volumes were determined using both T-1824 dye and radioactive chromium for each value.

Anemia, of itself, has been generally accepted to be unaccompanied by arterial $\mathrm{O}_{2}$ desaturation (6). However, a study by Ryan and Hickam (21) showed 10 severely anemic patients to have an average A-a gradient of $20.5 \mathrm{~mm}$. $\mathrm{Hg}$ while breathing room air in comparison to an average gradient of $4.2 \mathrm{~mm}$. $\mathrm{Hg}$ in six normal controls similarly studied. Similar results have been obtained on five anemic patients without sickling in this laboratory. It would appear, however, that the degree of desaturation in patients with sickle cell disease is relatively greater than that to be expected on the basis of anemia alone. In the present study, the average hemoglobin level in the sickle cell patients was $2.6 \mathrm{Gm}$. higher than that in the patients studied by Ryan and Hickam despite which the A-a gradients were much larger in the sickle cell group.

\section{Disturbances in diffusion}

The A-a gradients measured while low levels of oxygen were being breathed clearly indicate that defects in diffusion were not the major factor causing desaturation, although it is apparent that some loss of diffusing capacity had occurred in most of the patients. A pronounced abnormality of the diffusing capacity of the lungs, as evidenced by a gross increase in A-a gradient, was present in four patients (Nos. 1, 3,11, 12). In all patients, the minute volume of ventilation remained close to normal, unaccompanied by subjective

TABLE VI

Blood samples obtained simultaneously from multiple sites while breathing various oxygen mixtures

\begin{tabular}{|c|c|c|c|c|c|c|c|c|}
\hline \multirow[b]{2}{*}{ Patient } & \multicolumn{2}{|c|}{ Left forearm vein } & \multicolumn{2}{|c|}{ Right forearm vein } & \multicolumn{2}{|c|}{ Brachial artery } & \multicolumn{2}{|c|}{ Pulmonary artery } \\
\hline & $\%$ Sat.* & $\mathrm{pO}_{2} \dagger$ & $\%$ Sat. & $\mathrm{pO}_{2}$ & \% Sat. & $\mathrm{pO}_{2}$ & $\%$ Sat. & $\mathrm{pO}_{2}$ \\
\hline 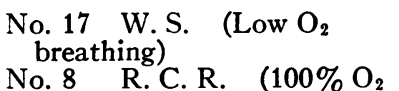 & 74.6 & 41 & 21 & 16 & 66.4 & 35 & & \\
\hline No. $8 \quad$ R.C. R. $\quad\left(100 \% \mathrm{O}_{2}\right.$ & 95.1 & 88 & 50 & 25 & 100 & 470 & 79 & 47 \\
\hline $\begin{array}{ll}\text { No. } 11 & \mathrm{R} . \mathrm{T} .\end{array} \quad\left(100 \% \mathrm{O}_{2}\right.$ & 76.8 & 45 & 100 & 256 & 100 & 596 & & \\
\hline $\begin{array}{l}\text { No. } 10 \\
\text { breathing) }\end{array}$ & 88.2 & 62 & 58.1 & 32 & 90.6 & 64 & 61 & 33 \\
\hline
\end{tabular}

* All oxygen saturations were determined by analysis for $\mathrm{O}_{2}$ content and capacity on the Van Slyke manometric apparatus.

$\dagger$ All $\mathrm{O}_{2}$ tension values were obtained by direct polarographic measurement. 
disturbances, even at very low concentrations of inspired oxygen (9 per cent).

\section{Pulmonary veno-arterial shunting}

The most important mechanism producing desaturation appears to have been right-to-left shunting within the pulmonary parenchyma. This is indicated by the large $\mathrm{A}-\mathrm{a} \mathrm{pO}_{2}$ gradients obtained while the patients breathed 100 per cent oxygen.

Two alternative causes for intrapulmonary shunting of blood from right-to-left in sickle cell patients appear possible. First, the shunting may be through anatomical veno-arterial channels which are present as a congenital malformation. Alternatively, the desaturation may be the result of blood traversing unaerated segments of the pulmonary parenchyma or moving through large vascular channels as a result of acquired changes in the lungs.

There is no concrete evidence for an increased incidence of generalized vascular abnormalities in sickle cell disease. Although dilated tortuous vessels have been demonstrated on microscopic pathological examination of the lungs as well as other organs in this disease (22), fistulous communications between arteries and veins are not described. Injection studies necessary to demonstrate such channels have, however, not been performed.

It is more likely that desaturation stems from pulmonary parenchymal alterations, presumably resulting from the frequent episodes of intrapulmonary difficulty to which these patients are subject. Pneumonia, pulmonary "sickle cell crises," and multiple pulmonary infarction have been invoked as a basis for the episodes.

The majority of the acute pulmonary attacks which have been observed in the subjects who form the background of this report have proved to be bacterial pneumonia with appropriate cultural confirmation and antibiotic response. There is also a possibility of the existence of some basic immunologic defect over and above the chronic anemic state.

The true nature of the clinical sickle cell crisis is obscure. It has been stated that, in order to compensate for the reduced oxygen carrying capacity found in any type of chronic anemia, an increased extraction of oxygen occurs peripherally and mixed venous blood has a lower than normal oxygen tension. This has been presumed to result in increased sickling within the central veins which, in turn, increases the viscosity of blood in the pulmonary vascular tree and slows the blood stream, resulting in sludging of cells with thrombosis in vessels and ischemic changes in surrounding tissues. The ischemia has been presumed to account for the symptoms which constitute a "crisis." Our studies do not support such a formulation. First, the values for pulmonary artery oxygen tension recorded while breathing room air (Table I) are higher, not lower, than would be expected from arterial $\mathrm{pO}_{2}$ levels. Second, even when a marked decrease in the pulmonary arterial $\mathrm{pO}_{2}$ with a concomitant increase in sickling was initiated by breathing of a low oxygen gas mixture, there was no evidence of any pathological process occurring within the lungs of any of these patients, either acutely or within a period of weeks from the time of study. Further, it is perhaps relevant that ventilatory studies provided no evidence of obliterative pulmonary vascular change; although all the patients showed decrease in vital capacity, the physiological dead space was normal in all.

\section{Peripheral arteriovenous shunting}

The presence of partially arterialized blood in certain peripheral veins is well established by these data. The demonstration of unusually high venous oxygen tensions in eight subjects while breathing 100 per cent $\mathrm{O}_{2}$ (Table IV) is particularly striking. The phenomenon suggests a peripheral arteriovenous shunting mechanism and has been noted in normal subjects by Permutt and Isaacs (23). Whether the phenomenon is more marked or more frequent in patients with sickle cell disease than in normal subjects or patients with other types of anemia is unknown. Our own studies of normal subjects and of patients with anemia of other types (24) suggest that sickle cell disease may be associated with peripheral arteriovenous shunting of unusual magnitude and the various mechanisms that may be involved are currently under study.

\section{Intracardiac hemodynamic relationships}

The cardiac catheterization findings were similar to results previously reported by Leight, 
Snider, Clifford, and Hellems (3). Despite the fact that cardiomegaly was present radiologically in almost all of these patients, the hemodynamic relationships, with one exception, were within normal limits. These findings do not substantiate the hypothesis that the cardiac enlargement in sickle cell disease is often due to cor pulmonale. Increased cardiac outputs and blood volumes, accompanied by normal pulmonary vascular resistances, indicate that the cardiac findings are principally those secondary to the high cardiac output. It is suggested that the mechanism producing these hemodynamic changes may be operative to a greater extent in sickle cell patients than in other comparably anemic patients because of a more profoundly decreased peripheral resistance, produced by extensive peripheral arteriovenous shunting.

\section{SUMMARY}

Unsaturation of the arterial blood has been demonstrated in 16 out of 21 patients possessing $S$ hemoglobin in various combinations.

By measuring A-a gradients on three levels of oxygenation, it has been determined that the desaturation is principally the result of intrapulmonary shunting of blood, although defects in diffusion also exist.

- Increased cardiac outputs and blood volumes were accompanied by generally decreased pulmonary vascular resistances, suggesting that cor pulmonale is not common in these states.

The administration of very low concentrations of oxygen (9 to 11 per cent), while producing increased sickling in both the arterial and venous circulation, resulted in no discernible acute or chronic symptomatology.

\section{ACKNOWLEDGMENT}

The aid of Dr. Elsie Smith and Dr. Leonor Oliveras during some of the studies, and the technical assistance of Mr. Bernard Williams and Mr. Claude McCain, Jr., are gratefully acknowledged.

\section{REFERENCES}

1. Klinefelter, H. F. The heart in sickle cell anemia. Amer. J. med. Sci. 1942, 203, 34.

2. Reinhard, E. H., Moore, C. V., Dubach, R., and Wade, L. J. Depressant effects of high concen- trations of inspired oxygen on erythrocytogenesis. Observations on patients with sickle cell anemia with a description of the observed toxic manifestations of oxygen. J. clin. Invest. 1944, 23, 682.

3. Leight, L., Snider, T. H., Clifford, G. O., and Hellems, H. K. Hemodynamic studies in sickle cell anemia. Circulation 1954, 10, 653.

4. Halden, E. R., Sproule, B. J., Clarke, R. L., Muirhead, E. E., and Miller, W. F. Effects of $\mathrm{O}_{2}$ breathing on the sickling phenomenon in vivo in sickle cell anemia and its variants (abstract). Amer. J. Med. 1957, 22, 966.

5. Sproule, B. J., Halden, E. R., and Miller, W. F. Arterial oxygen desaturation in patients with S-type hemoglobin patterns (abstract). Clin. Res. Proc. 1957, 5, 138.

6. Jensen, W. N., Rucknagel, D. L., and Taylor, W. J. Arterial oxygen unsaturation and possible mechanisms of its production in sickle cell anemia (abstract). J. clin. Invest. 1957, 36, 905.

7. Lilienthal, J. L., Jr., Riley, R. L., Proemmel, D. D., and Franke, R. E. An experimental analysis in man of the oxygen pressure gradient from alveolar air to arterial blood during rest and exercise at sea level and at altitude. Amer. J. Physiol. 1946, 147, 199.

8. Berggren, S. M. The oxygen deficit of arterial blood caused by nonventilating parts of the lung. Acta physiol. scand. 1942, 4, Suppl. 11.

9. Consolazio, C. F., Johnson, R. E., and Marek, E. Metabolic Methods. Clinical Procedures in the Study of Metabolic Functions. St. Louis, C. V. Mosby Co., 1951, p. 309.

10. Riley, R. L., Proemmel, D. D., and Franke, R. E. A direct method for determination of oxygen and carbon dioxide tensions in blood. J. biol. Chem. 1945, 161, 621.

11. Sproule, B. J., Miller, W. F., Cushing, I. E., and Chapman, C. B. An improved polarographic method for measuring oxygen tension in whole blood. J. appl. Physiol. 1957, 11, 365.

12. Scholander, P. F. Analyzer for accurate estimation of respiratory gases in one-half cubic centimeter samples. J. biol. Chem. 1947, 167, 235.

13. Halden, E. R., Sproule, B. J., Clarke, R. L., and Muirhead, E. E. In preparation.

14. Crosby, W. H., and Furth, F. W. A modification of the benzidine method for measurement of hemoglobin in plasma or urine. Blood 1956, 11, 380.

15. Comroe, J. H., Jr., Forster, R. E., DuBois, A. B., Briscoe, W. A., and Carlsen, E. The Lung. Chicago, Year Book Publishers, Inc., 1955, p. 81.

16. Riley, R. L., and Cournand, A. 'Ideal' alveolar air and the analysis of ventilation-perfusion relationships in the lungs. J. appl. Physiol. 1949, 1, 825.

17. Singer, R. B., and Hastings, A. B. An improved clinical method for the estimation of disturbances 
of acid-base balance of human blood. Medicine 1948, 27, 223.

18. Wilson, R. H., Ebert, R. V., Borden, C. W., Pearson, R. T., Johnson, R. S., Falk, A., and Dempsey, M. E. The determinations of blood flow through nonventilated portions of the normal and diseased lung. Amer. Rev. Tuberc. 1953, 68, 177.

19. Forssander, C. A. Alveolar air changes following inhalation of carbon dioxide during exercise and calculation of cardiac output. J. appl. Physiol. 1956, 8, 509.

20. Miller, W. F., Johnson, R. L., Jr., and Wu, N. The half-second expiratory capacity test: A convenient means of evaluating the nature and extent of pulmonary ventilatory insufficiency. Dis. Chest 1956, 30, 33.

21. Ryan, J. M., and Hickam, J. B. The alveolar-arterial oxygen pressure gradient in anemia. J. clin. Invest. 1952, 31, 188.

22. Kimmelstiel, P. Vascular occlusion and ischemic infarction in sickle cell disease. Amer. J. med. Sci. 1948, 216, 11.

23. Permutt, S., and Isaacs, M. Studies on oxygen saturation in superficial veins of the forearm (abstract). Clin. Res. Proc. 1957, 5, 173.

24. Halden, E. R., and Sproule, B. J. Unpublished data. 